\author{
Anna Vorontsova, \\ Ph.D., Sumy State University, Ukraine \\ iD ORCID ID, 0000-0003-0603-3869,
}

email: a.vorontsova@uabs.sumdu.edu.ua

Tetyana Mayboroda,

Ph.D., Sumy State University, Ukraine

iD ORCID ID, 0000-0002-4547-5822,

email: t.majboroda@management.sumdu.edu.ua

Hlib Lieonov,

Technical University of Hamburg, Germany

email: hlib@lieonov.com

Correspondence author: a.vorontsova@uabs.sumdu.edu.ua

\title{
INNOVATION MANAGEMENT IN EDUCATION: IMPACT ON SOCIO-LABOUR RELATIONS IN THE NATIONAL ECONOMY
}

\begin{abstract}
Education plays an essential role in the national economy and is responsible for the formation of qualified and competent human resources that will act in the labour market as a labour force. At the same time, in the conditions of rapid acceleration of socio-cultural and scientific-technical changes, the updating of knowledge and acquired competencies becomes compulsory today. Therefore, there is an unconditional connection between the sphere of socio-labour relations and the field of education. Despite this, today in Ukraine there is an imbalance between these areas, which are oversaturation of the labour market by some professionals (including economic and legal), and lack of others (including labour professions), labour migration, the dissatisfaction of employers with the level of knowledge of graduates, etc. It requires the modernization of the existing situation and the coordination at the state level of the areas of interaction between socio-labour relations and education sector. In this regard, this article is devoted to the justification of the impact of state regulation of education on the development of socio-labour relations in the national economy, which will be carried out by combining the method of principal components and logit modelling in the software STATA 11. To identify the integrated level characterizing the state of socio-labour relations in the national economy of Ukraine, numerous absolute and relative indicators were analyzed, including unemployment and employment levels, labour productivity, wage arrears and its average level, etc. The results obtained suggest an improvement in the socio-labour relations in Ukraine in recent years. Logit modelling allows confirming, as well as comprehensively and individually, the impact of macroeconomic, demographic, migration parameters, and a set of performance characteristics of the education sector on the level of harmonization and convergence of processes in labour markets and educational services. It helps to define the priorities of state intervention in the field of state regulation of education. The set calculations form the basis of further research of authors in the field of the specified problems.
\end{abstract}

Keywords: state regulation of education, socio-labour relations, national economy, labour market, binary logit modelling.

Introduction. In the national economic system of any country, all its links and components should work in unity and interdependence. Only under these conditions socio-economic growth and sustainable development of the state are possible. The education sector and the sphere of socio-labour relations belong to basic and essential components of the national economy.

Their sufficient work provides both productive and non-productive spheres of activity by skilled workers, and the economy as a whole by improving the population employment, balancing the load on the

Cite as: Vorontsova, A., Mayboroda, T., \& Lieonov, H. (2020). Innovation management in education: impact on socio-labour relations in the national economy. Marketing and Management of Innovations, 3, 346-357. http://doi.org/10.21272/mmi.2020.3-25 

National Economy

labour market and so on. However, the analysis of the current state and trends in education and sociolabour relations in Ukraine over the past 18 years has revealed significant educational disparities in the national economy. They are manifested in the high level of youth unemployment, i.e. among people who have just graduated from schools. The persons occupied a rather high share of the unemployed with vocational and complete higher education and the largest one in the labour market was the need for workers of vocational professions with vocational and technical education. All the above trends indicate an imbalance in the work of education and socio-labour relations, to identify the relationship between which this work will be devoted.

Literature review. The issue of ensuring an efficient labour market, which is an integral part of sociolabour relations in the national economy, is quite relevant for all countries (Dave, 2018a,b). One of the most significant problems in this context is the level of employment and unemployment, to which special attention is paid, in particular at the level of the European Union (Palova and Vejacka, 2018; Okuneviciute Neverauskiene and Rakauskiene, 2018, Dimian et al., 2018; Chocholata and Furkova, 2018; Banociova and Martinkova, 2017). Thus, numerous studies are aimed at studying the impact of individual indicators of the labour market on the state of economic development (Remeikiene and Gaspareniene, 2019, Sasongko and Huruta, 2019, Rollnik-Sadowska and Dąbrowska, 2018, Gedek et al., 2017) and its sustainable development (Fedulova et al., 2019, Mursa et al., 2018, Vasilyeva et al., 2018). Quite interesting is the work of Cyrek (2017), which examines the social effects of employment policy on the example of three sectors of the national economy - agricultural, industrial and service sectors.

The labour market is always in motion, which is manifested through labour migration both at the national level and internationally, a detailed study of which is presented in the work of Papp et al. (2018), Kleinschmidt (2017), Panthamit (2017), Drobyazko et al. (2019), Bilan et al. (2019). Also, in the work of Harmider et al. (2019) proved the impact of labour potential on regional competitiveness, and in the work of Lialina (2019) demonstrated its effects on national security. The link between education and the labour market is unquestionable and needs to be recognized at the level of strategic documents of government programs. In this regard, numerous studies are devoted to the system of lifelong education (Vasylieva et al., 2017, Pryima et al., 2018), knowledge creation and firm performance results (Vidic, 2018), entrepreneurial initiatives (Bilan et al., 2019), knowledge management (Poor et al., 2018, Anatan, 2018) and new requirements for the labour market and labour migrants, including the development of soft skills (Bardy et al., 2017), the development of dual education (Rayter and Davlikanova, 2017). Insufficient attention is paid to the issue of harmonization and convergence of processes taking place in the labour markets (as a manifestation of the sphere of socio-labour relations) and educational services, and to the level of their state regulation. Based on this, the purpose of this work is to substantiate the impact of state regulation of education on the development of socio-labour relations in the national economy.

Methodology and research methods. On the one hand, the labour market very clearly reflects the state of the national economy, as well as the problems and opportunities for the development of society as a whole (especially its social sphere). Thus, the method of analysis based on data on supply and demand, which are aggregate identifiers of the current state in the field of socio-labour relations of Ukraine, would be indicated in this sense. However, the task of concretizing processes and phenomena occurring in the national economy and society, as a whole, requires the use of the reverse direction of the analysis. Examining the regulation of education in the context of the national economy of Ukraine, which in turn is directly related to changes in labour, it was chosen the methodology and, accordingly, a set of indicators that most comprehensively form an idea of the reasons for the current state of complementary markets (educational services market and labour market). That is, we will involve indicators that allow us to conclude the state of the sphere of socio-labour relations, the corresponding dynamics and factors of change. To do this, we have calculated a general integrated indicator that describes the current state of the sphere of socio-labour relations in the national economy. This calculation is based on factor analysis - the 
A., Vorontsova, T., Mayboroda, H., Lieonov. Innovation Management in Education: Impact on Socio-Labour Relations in the National Economy

principal components analysis (PCA), which allows a large number of variables that identify the state of sociolabour relations, to consider the most significant one with deep (latent) relationships and determine the weight of their impact. Another advantage of the chosen calculation method is that the obtained indicators and their factor loads range from 0 to 1 (which is a necessary condition for further calculations).

The essence of the principal component analysis is primarily in the transition from a large number of features to the most significant factors (components) that describe them. The first factor F1 determines the direction in the space of initial elements, according to which the set of objects (points) has the largest distribution (variance); the second F2 is relative to the residual variance and so on (Tomashevich, 1999). Note that the factor loads are quite similar to the correlation coefficients, because they reflect the density of the relationship, but between the indicator and the corresponding component. Mathematically, this is expressed as follows:

$$
F_{k}=w_{k 1} Z_{1}+w_{k 2} Z_{2}+\ldots w_{k n} Z_{n}, k=\overline{1, r}
$$

where $w_{k n}$ - factor load of the component $F_{k}$ on the sign $Z_{j}$

The software package STATA 11 is used to process statistical data and perform all calculations by the principal component analysis and define the integrated indicator that describes the current state of the sphere of socio-labour relations. As a result of a thorough study on the selection of indicators that most fully allow us to conclude the current state of socio-labour relations in the national economy of Ukraine, we decided on the following (Table 1). The period is 2000-2017, for each indicator the direction of influence is set stimulating (if the increase of the indicator positively affects the sphere of socio-labour relations) or destimulating (if the increase of the indicator negatively affects the sphere of socio-labour relations).

Table 1. An array of input data describing the current state of socio-labour relations

\begin{tabular}{|c|l|c|}
\hline Variable & \multicolumn{1}{|c|}{ Relevant indicator, unit of measurement } & Direction of influence \\
\hline $\mathrm{y}_{1}$ & The unemployment rate of the population aged $15-70, \%$ & Destimulant \\
\hline $\mathrm{y}_{2}$ & The employment rate of the population aged $15-70, \%$ & Stimulant \\
\hline $\mathrm{y}_{3}$ & Labour productivity, UAH / person & Stimulant \\
\hline $\mathrm{y}_{4}$ & Wage arrears at the beginning of the year, mln. UAH & Destimulant \\
\hline $\mathrm{y}_{5}$ & The need for enterprises for employees, thousand people & Stimulant \\
\hline $\mathrm{y}_{6}$ & Load on one vacancy, people & Destimulant \\
\hline $\mathrm{y}_{7}$ & Use of working time fund, \% to working time fund & Stimulant \\
\hline $\mathrm{y}_{8}$ & The average duration of unemployment, months & Destimulant \\
\hline $\mathrm{y}_{9}$ & Average monthly salary, UAH & Stimulant \\
\hline $\mathrm{y}_{10}$ & $\begin{array}{l}\text { The average amount of unemployment benefits per month, } \\
\text { UAH (in December of the respective year) }\end{array}$ & Stimulant \\
\hline $\mathrm{y}_{11}$ & Youth unemployment rate, $\%$ & Destimulant \\
\hline
\end{tabular}

Source: developed by the authors.

One of the leading indicators describing the state of development of socio-labour relations in the national economy is the level of employment and unemployment, as well as labour productivity, which means «the ratio of total products and services to total labour costs or productivity at the macro-level» (Semykina, 2010). The issue of wages also plays a significant role in the field of socio-labour relations, which led to the inclusion of such indicators as arrears of salaries and the average monthly wage (which is an essential factor at both state and personal level). The input data set includes the leading indicators of labour demand and the workload, which are critical at the level of employers, as well as indicators of the average amount of unemployment benefits and its duration, the level of youth unemployment and 
A., Vorontsova, T., Mayboroda, H., Lieonov. Innovation Management in Education: Impact on Socio-Labour Relations in the National Economy

more. The selected indicators are used to analyze the state of development of socio-labour relations both at the national level (macro-level) and at the level of business entities - employers (meso-level), personal level of employees (micro-level). As a result of applying the module of descriptive statistics, it becomes evident that the selected indicators have different units of measurement, and therefore are incomparable for the calculation of the integrated indicator. To do this, let us carry out the procedure of their normalization, which allows us to compare them in the future. Its essence is mainly that the value of the analyzed indicator (yij) is compared with a certain value of a. We have chosen indicators of maximum and minimum values that allow us to consider the direction of variables influence. Normalized data is used to apply the principal component analysis in the program, which also allows you to determine the weight of each variable in the array of input data depending on their correlation and variance.

Note that to find the most optimal or unambiguous position of the axes in space, and hence determine the appropriate number of factors, the method of orthogonal rotation "varimax" was used. Intermediate results of PCA calculations and selected weights for each factor are given below (Table 2).

Table 2. Interim results of PCA calculations used to determine the state of development of sociolabour relations in the national economy of Ukraine

\begin{tabular}{|c|c|c|c|c|c|}
\hline \multicolumn{2}{|c|}{ Factor } & Variation & \multicolumn{2}{|c|}{ Proportion of variance } & Cumulative variance \\
\hline \multicolumn{2}{|l|}{ Factor 1} & 4.17808 & \multicolumn{2}{|c|}{0.3798} & 0.3798 \\
\hline \multicolumn{2}{|l|}{ Factor 2} & 3.96554 & \multicolumn{2}{|c|}{0.3605} & 0.7403 \\
\hline \multicolumn{2}{|l|}{ Factor 3} & 3582 & \multicolumn{2}{|c|}{0.1761} & 0.9163 \\
\hline \multicolumn{6}{|c|}{ Factor loads obtained as a result of rotation } \\
\hline Variables & Factor 1 & Factor 2 & Factor 3 & Uniqueness & Weight factor \\
\hline $\mathrm{y}_{1}$ & 0.0965 & -0.8854 & -0.1114 & 0.1943 & -0.1934 \\
\hline $\mathrm{y}_{2}$ & 0.0723 & -0.9211 & 0.3091 & 0.0511 & -0.2011 \\
\hline $\mathrm{y}_{3}$ & 0.9672 & 0.0963 & 0.2021 & 0.0144 & 0.2225 \\
\hline $\mathrm{y}_{4}$ & 0.269 & 0.9044 & -0.1834 & 0.076 & 0.1975 \\
\hline $\mathrm{y}_{5}$ & 0.5444 & -0.0568 & 0.7995 & 0.0611 & 0.0852 \\
\hline $\mathrm{y}_{6}$ & -0.1093 & 0.3481 & -0.8818 & 0.0893 & -0.0940 \\
\hline $\mathrm{y}_{7}$ & 0.1491 & 0.9248 & -0.0761 & 0.1167 & 0.2020 \\
\hline $\mathrm{y}_{8}$ & 0.5581 & 0.6906 & -0.0337 & 0.2104 & 0.1508 \\
\hline y9 & 0.9607 & 0.145 & 0.2101 & 0.0119 & 0.2210 \\
\hline $\mathrm{y}_{10}$ & 0.9524 & 0.1273 & 0.2596 & 0.0093 & 0.2191 \\
\hline $\mathrm{y}_{11}$ & 0.8268 & -0.1111 & -0.4671 & 0.0861 & 0.1902 \\
\hline
\end{tabular}

Source: developed by the authors.

As a result of the rotation, only three factors with a cumulative variance of $91.63 \%$ were identified. Also, the selected number of factors satisfies other criteria that exist in the conduct of the PCA (in particular, the Kaiser test, as well as the Kettle test). Factor loads with a value greater than $70 \%$ were used to calculate the weight value for the variables. The data obtained indicate a sufficient uniformity in a load of most indicators. The integrated indicator describing the state of development of the sphere of sociolabour relations is calculated according to the following equation (2), which provides for weighing the normalized data for the weight estimated for them:

$$
I_{l m}=\sum \bar{y}_{i j} w_{i},
$$

where $I_{l m}$ - integral indicator describing the state of development of the sphere of socio-labour relations for the j-th year; $w_{i}$ - the weight of the i-th indicator; $\bar{y}_{i j}$ - the normalized value of the i-th indicator for the j-th year. 
A., Vorontsova, T., Mayboroda, H., Lieonov. Innovation Management in Education: Impact on Socio-Labour Relations in the National Economy

The obtained results of calculations describing the integrated state of development of the sphere of socio-labour relations in the national economy of Ukraine for 200-2017 are given below (Fig. 1).

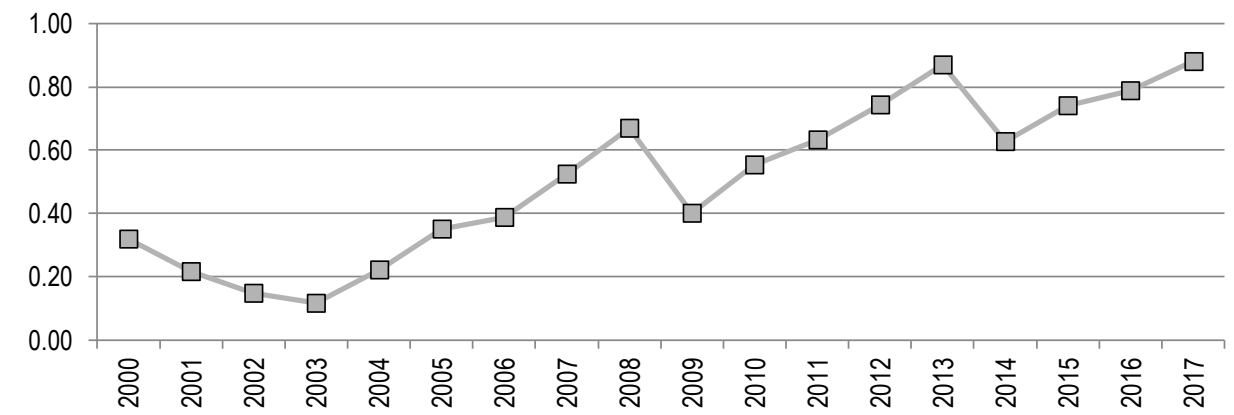

Figure 1. Dynamics of the integrated indicator that describes the state of development of sociolabour relations in the national economy of Ukraine for 2000-2017, units

Source: developed by the authors.

According to the obtained values of the integrated indicator, the state of development of the sphere of socio-labour relations in the national economy of Ukraine analyzed in dynamics cannot be called stable. The crisis years were 2002, 2009, 2014, which is reflected in the form of sharp declines in the planned dynamics. These are periods when the country's economy has experienced significant economic problems, which has led to job losses, cessation of activities of certain financial entities, inflationary fluctuations, and so on. However, there is reason to believe that the situation in the field of socio-labour relations in Ukraine has begun to improve. The graph constructed above quite naturally reflects such a tendency. To assess the appropriate level of development of socio-labour relations, we have chosen a verbal-numerical modified Harrington scale, which is quite universal and is used to evaluate various qualitative indicators (Table 3).

Table 3. Qualitative assessment of the integrated indicator describing the sphere of socio-labour relations in the national economy based on the modified Harrington scale

\begin{tabular}{|l|l|}
\hline \multicolumn{1}{|c|}{ Range of values } & \multicolumn{1}{c|}{ Qualitative characteristics } \\
\hline $1.00-0.69$ & High level \\
\hline $0.68-0.37$ & Satisfactory or acceptable level \\
\hline $0.36-0.00$ & Unacceptable or marginal (crisis) level \\
\hline
\end{tabular}

Source: developed by the authors based on (Harrington, 1965).

The above scale suggests that in the period after the global financial crisis, the development of sociolabour relations in the national economy of Ukraine has resumed positive dynamics also continued after 2014 compared to the beginning of the military-political conflict. The hope for the possibility of approving qualitative changes in the field of socio-labour relations in the national economy confirms the fact of improvement. However, it should be noted that the calculated state of the sphere of socio-labour relations is determined only based on a limited number of official statistical indicators, describing certain aspects of its operation. Meanwhile, Ukraine has a high percentage of hidden unemployment and informal employment, which significantly distorts the official statistics of the country. Analyzing the leading indicators, identifying the state of the labour market revealed an imbalance of supply and demand, disparities in the educational and qualification structure of employees, etc. All this indicates that the labour market cannot be studied in isolation from other complementary market systems, primarily in the field of 
educational services. Summarizing the calculations, we note, that the labour market plays a significant role in the economy of any country because it ensures the rotation of such goods as labour, which is one of the main factors of production. Given this, this area of the economy requires state participation and regulation in the context of establishing a balance of socio-labour relations and the functioning of other economic and social spheres. The above data indicate a close relationship between the state of development of socio-labour relations in the national economy and the globe of references, related to education. At the same time, the mathematical equation icon of the problem of assessing such a relationship is primarily in the study of changes in the state of socio-labour relations (as a particular value) under the influence of the transformation of education and other socio-economic factors, in particular, under the conditions of their state regulation. As part of the study, we made assumptions, that the change in the state of development of the sphere of socio-labour relations can occur in two directions improvement and deterioration. Conditionally, this situation is reduced to the probability of occurrence or non-occurrence of a particular crisis event. For solving this question, the construction of logit and probit models standard in scientific practice is used. Its difference is mainly in the specifics of dependence modelling:

- the logistic distribution function is used for the logit model:

$$
F(x)=\frac{e^{x}}{1+e^{x}}
$$

$F(x)$ - the standard normal distribution function is used for the probit model:

$$
F(x)=\frac{1}{\sqrt{2 \pi}} \int_{-\infty}^{x} e^{-\frac{t^{2}}{2}} d t .
$$

The maximum-likelihood technique is used in both methods to find estimates of model parameters. The logistic distribution is very similar to the normal distribution. Accordingly, the unambiguous choice regarding the application of one of the types of models is a difficult question. It is known that for small samples and samples with a small distribution of independent variables, the conclusions on the logit and probit models will almost coincide (Matviychuk and Ben, 2015). The integrated indicator was used as an independent variable, describing the state of development of socio-labour relations in the national economy. To do this, the obtained values of this indicator must be transformed into binary values, taking values of either 0 (if the state of the sphere of socio-labour relations was unsatisfactory) or 1 (if the form of the sphere of socio-labour relations was satisfactory). This transformation was carried out based on the rule of mathematical rounding of results. The following blocks of indicators were chosen to form an array of dependent variables in addition to educational factors (performance indicators of the education sector), consider additional macroeconomic and demographic and migration indicators (Table 4). As a result, the array of input variables is denoted as $X=(x i),(i=1, n)$. These indicators are given for the period 2000 2017 on average in Ukraine. The findings proved that among indicators of the branch of educational services, the financing of education by the public sector is identified, which provides one of the necessary forms of the state regulation. Other indicators of this block are also formed under the influence of various administrative and financial instruments of state regulation.

In this regard, the logit model, which describes the probability of change in the state of development of socio-labour relations in the national economy depending on macroeconomic, demographic and migration and performance indicators of the education sector will be as follows (equation 5). 
A., Vorontsova, T., Mayboroda, H., Lieonov. Innovation Management in Education: Impact on Socio-Labour Relations in the National Economy

Table 4. An array of dependent variables, describing the block of macroeconomic, demographic and migration and performance indicators of the education sector

\begin{tabular}{|c|c|c|}
\hline Block of indicators & Indicators & Symbols \\
\hline \multirow{7}{*}{$\begin{array}{l}\text { Macroeconomic } \\
\left(X_{1}\right)\end{array}$} & GDP at actual prices, mln. UAH & $x_{1}$ \\
\hline & Consumer price index, $\%$ to the previous month & $x_{2}$ \\
\hline & Producer price indices of industrial products, $\%$ & $x_{3}$ \\
\hline & Industrial production indices by type of activity, $\%$ & $x_{4}$ \\
\hline & Gross output index of agriculture, $\%$ & $x_{5}$ \\
\hline & Index of the volume of construction work performed, $\%$ & $X_{6}$ \\
\hline & Retail trade volume index, $\%$ & $X_{7}$ \\
\hline \multirow{3}{*}{$\begin{array}{l}\text { Macroeconomic } \\
\left(X_{1}\right)\end{array}$} & The total amount of state and state-guaranteed debt, bln. UAH & $X_{8}$ \\
\hline & Direct investments in Ukraine, mln. USD & $X_{9}$ \\
\hline & Disposable income, mln. UAH & $x_{10}$ \\
\hline \multirow{3}{*}{$\begin{array}{l}\text { Demographic and } \\
\text { migration }\left(X_{2}\right)\end{array}$} & Population available, as of January 1 ; thousand people & $x_{11}$ \\
\hline & Natural increase, decrease (-), thousand people & $X_{12}$ \\
\hline & Migration growth, reduction (-), thousand people & $x_{13}$ \\
\hline \multirow{8}{*}{$\begin{array}{l}\text { Performance indicators of } \\
\text { the education sector }\left(X_{3}\right)\end{array}$} & Number of vocational education institutions (VEI), units & $X_{14}$ \\
\hline & Number of higher education institutions (HEls), units & $X_{15}$ \\
\hline & Trained (released) skilled workers, thousand & $x_{16}$ \\
\hline & Number of graduates of the $\mathrm{HEl}$, units & $X_{17}$ \\
\hline & The share of employed graduates of vocational education institutions, $\%$ & $X_{18}$ \\
\hline & The share of graduates of HEls who received a job assignment, $\%$ & $X_{19}$ \\
\hline & Public sector education financing & $x_{20}$ \\
\hline & Financing of education by the private sector & $x_{21}$ \\
\hline
\end{tabular}

Source: developed by the authors.

$$
Y_{j}=b_{0}+b_{1} X_{1}+b_{2} X_{2}+b_{3} X_{3}+\varepsilon \text {. }
$$

where $Y_{t}$ - an integrated indicator that describes the state of the sphere of socio-labour relations in the national economy for the $j$-th year and is presented in the form of a binary variable; $b_{0}-$ free member of the model; $b_{i}$ - coefficients of the logit-regression equation; $X_{i}$ - groups of variables, which describe macroeconomic, demographic and migration and indicators of the functioning of the education sector; $\varepsilon-$ standard model error.

For bring the indicators for the commensurate form, it was decided to normalize them to the maximum and minimum values). Besides, these indicators for three blocks were analyzed by the factor analysis method and their impact on the quality of the model (in particular, the level of significance of the $p$-criterion, the adequacy of the model and the schedule of the normal distribution of balances). As a result of these actions, we have reduced the initial list to the following variables:

- $\quad$ producer price indices of industrial products, \% (x3);

- $\quad$ indices of industrial products by type of activity, $\%(x 4)$;

_ $\quad$ index of gross agricultural output, \% (x5);

- $\quad$ index of the volume of construction work performed, $\%(x 6)$;

- $\quad$ retail trade volume index, \% $(x 7)$;

- $\quad$ number of vocational education institutions, units (x14);

- number of higher education institutions, units (x15);

- $\quad$ share of graduates of higher education institutions, who received a referral to work, $\%(x 19)$;

- $\quad$ financing education by the private sector (x21).

The study aimed to identify the impact of factors on the state of development of socio-labour relations in the national economy as in the context of each variable $\mathrm{x}$ and separately for these blocks $\mathrm{X}$. For this 
A., Vorontsova, T., Mayboroda, H., Lieonov. Innovation Management in Education: Impact on Socio-Labour Relations in the National Economy

purpose, integrated indicators for macroeconomic (X1), demographic and migration (X2) factors and performance indicators of the education sector $(X 3)$ are calculated. As a basis, the technique was taken, which allows using the principal components analysis to detect the weight of each variable based on the values of factor load and variance and calculate the integral costs. These values were the basis of logit regression, which was calculated using the software package STATA 11 and has the following form:

$$
Y_{j}=-13,42+25,11 X_{1}-0,69 X_{2}+3,04 X_{3}
$$

This model proves the existence of an adequate and significant relationship (Tables 5,6 ) between the integrated indicator of the state of development of socio-labour relations and the blocks of macroeconomic (X1), demographic and migration (X2) and performance indicators of education (X3). In this case, when growing by one:

- a set of macroeconomic factors, the state of development of the sphere of socio-labour relations in the national economy will increase by 25.11 units;

- a group of demographic and migration factors, the state of development of the sphere of sociolabour relations in the national economy will decrease by 0.69 units;

- a set of elements in the functioning of the education sector, the state of development of the sphere of socio-labour relations in the national economy will increase by 3.04 units.

Table 5. Available and predicted values of the objective function, describing the complex relationship between the integrated indicator of the state of development of the sphere of sociolabour relations and blocks X1, X2 and X3

\begin{tabular}{|l|c|c|c|}
\hline Years & Available values & Estimated values & Balances \\
\hline 2000 & 0.000000 & 0.001905 & -0.001905 \\
\hline 2001 & 0.000000 & 0.007689 & -0.007689 \\
\hline 2002 & 0.000000 & 0.014965 & -0.014965 \\
\hline 2003 & 0.000000 & 0.015386 & -0.015386 \\
\hline 2004 & 0.000000 & 0.017200 & -0.017200 \\
\hline 2005 & 0.000000 & 0.045811 & -0.045811 \\
\hline 2006 & 0.000000 & 0.151852 & -0.151852 \\
\hline 2007 & 1.000000 & 0.826683 & 0.173317 \\
\hline 2008 & 1.000000 & 0.807888 & 0.192112 \\
\hline 2009 & 0.000000 & 0.256630 & -0.256630 \\
\hline 2010 & 1.000000 & 0.959591 & 0.040409 \\
\hline 2011 & 1.000000 & 0.990925 & 0.009075 \\
\hline 2012 & 1.000000 & 0.997175 & 0.002825 \\
\hline 2013 & 1.000000 & 0.998334 & 0.001666 \\
\hline 2014 & 1.000000 & 0.971862 & 0.028138 \\
\hline 2015 & 1.000000 & 0.802890 & 0.197110 \\
\hline 2016 & 1.000000 & 0.942708 & 0.057292 \\
\hline 2017 & 1.000000 & 0.990508 & 0.009492 \\
\hline
\end{tabular}

Source: developed by the authors.

While examining each selected variable influence on the selected blocks, the following results were obtained (which also correspond to the conditions of an adequate model - Tables 9 and 10):

$$
\begin{aligned}
& Y_{j}=-10,44+36,31 x_{1}-28,66 x_{2}-4,87 x_{8}+18,11 x_{9}+4,08 x_{10}-20,23 x_{11}-2,91 x_{12}- \\
& -4,68 x_{13}+1,04 x_{16}+3,81 x_{17}+5,36 x_{18}+26,24 x_{20}
\end{aligned}
$$


A., Vorontsova, T., Mayboroda, H., Lieonov. Innovation Management in Education: Impact on Socio-Labour Relations in the National Economy

The above model is a more complicated case of the first model because it allows taking into account the impact of each indicator of selected blocks (macroeconomic, demographic and migration and performance indicators of education) on the state of socio-labour relations in the national economy.

Table 6. The adequacy of the constructed model

\begin{tabular}{|c|c|c|c|c|}
\hline Observation & Observation ID & Prediction 1 & Prediction 0 & $\%$ of correct classification \\
\hline Satisfactory condition & 1 & 8 & 0 & 97.50000 \\
\hline Unsatisfactory condition & 0 & 0 & 10 & 98.00000 \\
\hline
\end{tabular}

Source: developed by the authors.

In the context of our study, the most significant interest is the unit of the effectiveness of the education sector, which proves the existence of an adequate and meaningful connection: with an increase per unit of the number of trained (released) skilled workers (x16), the state of development of socio-labour relations in the national economy will increase by 1.04 units; with the growth per unit of the number of graduates of HEls (x17), the state of development of the sphere of socio-labour relations in the national economy will increase by 3.81 units; with the growth per unit of the share of employed graduates of VEIs (x18), the state of development of the sphere of socio-labour relations in the national economy will increase by 5.36 units; with an increase in the share of education financing by the public sector per unit (x20), the state of development of socio-labour relations will increase by 26.24 units.

Table 7. Existing and predicting values of the target function, which describes the element-byelement relationship between the state of development of socio-labour relations and individual indicators of the block of macroeconomic, demographic and migration and the effectiveness of the education sector

\begin{tabular}{|c|c|c|c|c|c|c|c|}
\hline Years & $\begin{array}{c}\text { Available } \\
\text { values }\end{array}$ & Estimated values & Balances & Years & $\begin{array}{c}\text { Available } \\
\text { values }\end{array}$ & Estimated values & Balances \\
\hline 2000 & 0.000000 & 0.000000 & -0.000000 & 2009 & 0.000000 & 0.421440 & -0.421440 \\
\hline 2001 & 0.000000 & 0.000000 & -0.000000 & 2010 & 1.000000 & 0.909996 & 0.090004 \\
\hline 2002 & 0.000000 & 0.000000 & -0.00000 & 2011 & 1.000000 & 0.886591 & 0.113409 \\
\hline 2003 & 0.000000 & 0.000000 & -0.000000 & 2012 & 1.000000 & 0.997326 & 0.002674 \\
\hline 2004 & 0.000000 & 0.000000 & -0.000000 & 2013 & 1.000000 & 0.910904 & 0.089096 \\
\hline 2005 & 0.000000 & 0.000000 & -0.000000 & 2014 & 1.000000 & 1.000000 & 0.000000 \\
\hline 2006 & 0.000000 & 0.000000 & -0.000000 & 2015 & 1.000000 & 1.000000 & 0.000000 \\
\hline 2007 & 1.000000 & 0.861387 & 0.138613 & 2016 & 1.000000 & 1.000000 & 0.000000 \\
\hline 2008 & 1.000000 & 0.999999 & 0.000001 & 2017 & 1.000000 & 1.000000 & 0.000000 \\
\hline
\end{tabular}

Source: developed by the authors.

At the same time, it should note the significant impact of macroeconomic factors influencing the state of development of socio-labour relations. In particular, when changing indicators such as GDP, direct investment and disposable income, there is an improvement in the dependent variable; when changing the consumer price index and the total amount of public and guaranteed debt - deterioration. Demographic and migration factors have an inverse effect on the state of development of socio-labour relations.

Table 8. The adequacy of the constructed model

\begin{tabular}{|c|c|c|c|c|}
\hline Observation & Observation ID & Prediction 1 & Prediction 0 & $\%$ of correct classification \\
\hline Satisfactory condition & 1 & 8 & 0 & 100.0000 \\
\hline Unsatisfactory condition & 0 & 0 & 10 & 100.0000 \\
\hline
\end{tabular}

Source: developed by the authors. 
A., Vorontsova, T., Mayboroda, H., Lieonov. Innovation Management in Education: Impact on Socio-Labour Relations in the National Economy

Conclusions. The study confirms that changes in the state of development of socio-labour relations in the national economy towards improvement or deterioration are due to many factors of macroeconomic, demographic and migratory nature and performance indicators of the education sector. Moreover, educational factors both in aggregate in the form of an integral indicator (for the 3rd block of factors) and separately (according to indications: trained (graduated) skilled workers and graduates of HEls, the share of employed graduates of vocational education institutions and institutions of higher education, funding education by the public sector) have a significant direct connection. It suggests that the development of the labour market, which significantly forms the sphere of socio-labour relations in the national economy is influenced by numerous factors (macroeconomic, demographic and migration and the effectiveness of the education sector). At the same time, thanks to the last block, the need for state participation is proved. Its role cannot be underestimated, after all, with the help of various measures and tools of direct and indirect influence from the state, the adjustment of the processes of training and employment of skilled labour is carried out. Effective state policy in this area creates the preconditions for ensuring the balance of complementary markets for educational services and labour and improves the overall socio-economic situation in the country.

Author Contributions: conceptualization, methodology, writing-review and editing A. V., T. M., H. L.

Acknowledgements. The article was executed in the framework of state budget scientific research works: Registration No. 0120 U102001.

\section{References}

Anatan, L. (2018). An institutional perspective of knowledge transfer within university and industry alliance. International Journal of Economic Policy in Emerging Economies, 11(4), 378-395. [Google Scholar] [CrossRef]

Banociova, A., \& Martinkova, S. (2017). Active Labour Market Policies of Selected European Countries and Their Competitiveness. Journal of Competitiveness. 9(3), 5-21. [Google Scholar] [CrossRef]

Baranovskyi, O. I. (2020). Regulation of functional and structural transformational processes in the financial sector. Financial and credit activity: problems of theory and practice, 1(32), 292-306. [Google Scholar] [CrossRef]

Baranovskyi, O. I. (2018). Quality of the transformational processes in the financial sector of the national economy: vectors of the measurement. Financial and credit activity: problems of theory and practice, 3(26), 350-367. [Google Scholar] [CrossRef]

Bardy, R., Rubens, A., \& Eberle, P. (2017). Soft Skills and Job Opportunities of Migrants: Systemic Relationships in the Labour Market. Business Ethics and Leadership. 1(4), 5-21. [Google Scholar]

Bilan, Y., Sergi, B. S., \& Simionescu, M. (2019). Migration expectations and geography of post-Soviet Ukraine. Oeconomia Copernicana, 10(4), 603-625. [Google Scholar] [CrossRef]

Bilan, Y., Simionescu, M., Mentel, G., \& Rozsa, Z. (2019). The role of education, individual and economic factors in entrepreneurial initiatives: A microeconomic approach for the Czech Republic, Slovakia and Poland. E \& $M$ Ekonomie a Management, 22(4), 85-103. [Google Scholar] [CrossRef]

Boiarko, I. M. (2016). Praxeological and situational approaches in the formation of strategic accounting. Financial and credit activities: problems of theory and practice, 2(21), 80-90. [Google Scholar] [CrossRef]

Chocholata, M., \& Furkova, A. (2018). The analysis of employment rates in the context of spatial connectivity of the EU regions. Equilibrium. Quarterly Journal of Economics and Economic Policy, 13(2), 181-213. [Google Scholar] [CrossRef]

Cyrek, M. (2017). Social efficiency of employment in three sectors-a comparison of Polish regions. Equilibrium. Quarterly Journal of Economics and Economic Policy, 12(3), 417-432. [Google Scholar] [CrossRef]

Dave. H. (2018a). Elementary investigation on Division of Labour. Part 1. Financial Markets. Institutions and Risks. 2(3), 87103. [Google Scholar] [CrossRef]

Dave. H. (2018b). Elementary investigation on Division of Labour- Part 2. Financial Markets. Institutions and Risks. 2(4), 39-56. [Google Scholar] [CrossRef]

Dimian, G. C., Aceleanu, M. I., lleanu, B. V., \& Serban, A. C. (2018). Unemployment and sectoral competitiveness in Southern European Union countries. Facts and policy implications. Journal of Business Economics and Management, 19(3), 474-499. [Google Scholar] [CrossRef]

Drobyazko, S., Alieksieienko, I., Kobets, M., Kiselyova, E., \& Lohvynenko, M. (2019). Transnationalisation and segment security of the international labour market. Journal of Security \& Sustainability Issues, 9(2). [Google Scholar] [CrossRef]

Dubrov. A.M. (1978). Processing of statistical data by the method of principal components. Moscow: Statistics. 


\section{A., Vorontsova, T., Mayboroda, H., Lieonov. Innovation Management in Education: Impact on Socio-Labour Relations in the}

National Economy

Fedulova, I., Voronkova, O. Y., Zhuravlev, P., Gerasimova, E., Glyzina, M., \& Alekhina, N. (2019). Labour productivity and its role in the sustainable development of economy: on the example of a region. Entrepreneurship and Sustainability Issues, 7(2), 10591073. [Google Scholar] [CrossRef]

Gavurova, B., Belas, J., Kotaskova, A., \& Cepel, M. (2018). Management of education concepts in the field of entrepreneurship of university students in the Czech Republic. Polish Journal of Management Studies, 17. [Google Scholar] [CrossRef]

Gedek, S., Misiak, T., \& Mentei, G. (2017). Changes in gdp and the employment and unemployment in the European Union. Transformations in Business \& Economics, 16. [Google Scholar]

Harmider, L., Taranenko, I., Honchar, L., Ovcharenko, O., \& Dotsenko, G. (2019). Modelling of Labour Potential as a Factor of Influence on the Region Competitiveness. Montenegrin Journal of Economics, 15(2), 111-125. [Google Scholar] [CrossRef]

Harrington, E. C. (1965). The desirable function/EC Har rington. Industrial Quality Control, 21(10), 124-131.

Hrytsenko, L. L., Roienko, V., \& Boiarko, I. M. (2018). Institutional background of the role of state in investment processes activation. Financial and credit activities: problems of theory and practice, 1(24), 338-344. [Google Scholar] [CrossRef] Kleinschmidt, H. (2017). Labour Movements, Mainly in Eastern Europe. SocioEconomic Challenges, 1(3), 45-50. [Google Scholar]

Kuznyetsova A. Ya., Zherebylo I. V., Klipkova O. I., Kozmuk N. I. (2019). Creation of the value of national enterprises with the help of the innovation centers in the cluster formations. Financial and credit activities: problems of theory and practice, 2(29), 391-402. [Google Scholar] [CrossRef]

Kuznyetsova, A. Y., \& Klishchuk, O. V. (2017). Theoretical conception of price stability targeting arrangement: investigation of basic principles of implementation monetary regime. Financial and credit activity: problems of theory and practice, 2(23), 388-396. [Google Scholar] [CrossRef]

Lialina, A. (2019). Labour market security in the light of external labour migration: new theoretical findings. Entrepreneurship and Sustainability Issues, 6(3), 1105-1125. [Google Scholar] [CrossRef]

Matviychuk, A., \& Ben, V. (2015). The use of logit and probit regressions to evaluate a borrower's creditworthiness. Bulletin of the National Bank of Ukraine, 5, 37-41.

Mursa, G. C., lacobuta, A. O., Socoliuc, O. R., Clipa, R. I., \& Butiseaca, A. (2018). Youth unemployment among EU countriesa challenge for sustainable growth and social cohesion. Transformations in Business \& Economics, 17. [Google Scholar]

Okuneviciute Neverauskiene, L., \& Rakauskiene, O. G. (2018). Identification of employment increasing possibilities in the context of the EU socio-economic environment evaluation: The case of Lithuania. Economics and Sociology, 11(4), 51- 68. CrossRef

Palova, D., \& Vejacka, M. (2018). Analysis of employment in the EU according to Europe 2020 strategy targets. Economics \& Sociology, 11(3), 96-112. [Google Scholar] [CrossRef]

Panthamit, N. (2017). The unemployment impact of immigrant workers in Thailand. International Journal of Trade and Global Markets, 10(1),108-114.

Papp, I. C., Bilan, S., \& Dajnoki, K. (2019). Globalization of the labour market-Circular migration in Hungary. Journal of International Studies, 12(2), 182-200. [Google Scholar] [CrossRef]

Pimonenko, T., \& Lushyk, K. (2017). Green investing: EU experience for Ukraine. Bulletin of Sumy State University. Economy Ser, 3 , 61-67. [Google Scholar] [CrossRef]

Pimonenko, T., Bilan, Y., Horák, J., Starchenko, L., \& Gajda, W. (2020). Green Brand of Companies and Greenwashing under Sustainable Development Goals. Sustainability, 12(4), 1679. [Google Scholar] [CrossRef]

Poor, J., Juhasz, T., Machova, R., Bencsik, A., \& Bilan, S. (2018). Knowledge management in human resource management: Foreign-owned subsidiaries' practices in four CEE countries. Journal of International Studies, 11(3), 295-308. [CrossRef] Pryima, S., Dayong, Y., Anishenko, O., Petrushenko, Y., \& Vorontsova, A. (2018). Lifelong learning progress monitoring as a tool for local development management. Problems and perspectives in management, 16(3), 1-13. [Google Scholar] Rayter, G., \& Davlikanova, O. Introduction of Dual Education in Ukrainian Higher Educational Establishments and Approaches to Estimation of its Economic Benefits. Business Ethics and Leadership, 1(4), 93-101. [Google Scholar]

Remeikiene, R., \& Gaspareniene, L. (2019). Assessment of the impact of emigration on the origin economy. Business: Theory and Practice, 20, 187. [Google Scholar] [CrossRef]

Rollnik-Sadowska, E., \& Dabrowska, E. (2018). Cluster analysis of effectiveness of labour market policy in the European Union. Oeconomia Copernicana, 9(1), 143-158. [Google Scholar] [CrossRef]

Sasongko, G., \& Huruta, A. D. (2019). The causality between inflation and unemployment: the Indonesian evidence. Business: Theory and Practice, 20, 1-10. [Google Scholar] [CrossRef]

Semykina, M. V. (2010). Labour productivity: measurement methodology. prerequisites for growth. Scientific papers of Kirovograd National Technical University. Economic sciences, 17, 457-463.

Sinaga, O., Lis, M., \& Razimi, M. S. A. (2019). Education and core skills in the performance with mediating role of employee innovation. Polish Journal of Management Studies, 19. [Google Scholar] [CrossRef

Tomashevich, V. N. (1999). Multidimensional Statistical Analysis in Economics. Moscow: UNITI-DANA.

Vasilyeva, T., Lyeonov, S., Adamickova, I., \& Bagmet, K. (2018). Institutional quality of social sector: The essence and measurements. Economics \& Sociology, 11(2), 248-262. [Google Scholar] [CrossRef] 
A., Vorontsova, T., Mayboroda, H., Lieonov. Innovation Management in Education: Impact on Socio-Labour Relations in the National Economy

Vasylieva, T., Lieonov, S., Petrushenko, Y., \& Vorontsova, A. (2017). Investments in the system of lifelong education as an effective factor of socio-economic development. Financial and Credit Activity: Problems Of Theory And Practice, 2(23), 426-436. [CrossRef]

Vasylieva, T., Lyeonov, S., Lyulyov, O., \& Kyrychenko, K. (2018). Macroeconomic stability and its impact on the economic growth of the country. Montenegrin Journal of Economics, 14(1), 159-170. [Google Scholar] [CrossRef]

Vidic, F. (2018). Entrepreneurial Orientation and Knowledge Creation and Their Impact on Company Performance. SocioEconomic Challenges, 2(3), 37-48. [Google Scholar]

Vovchak, O. D., Senyshch, P. M., \& Melnyk, T. V. (2019). «Purging» of the banking system: impacton the key performance indicators of banks. Financial and credit activity: problems of theory and practice, 1(28), 16-25. [Google Scholar] [CrossRef]

Анна Воронцова, к.е.н., Сумський державний університет, Україна

Тетяна Майборода, к.е.н.,Сумський державний університет, Україна

Гліб Лєонов, Технологічний університет Гамбурга, Німеччина

Інноваційний менеджмент в освіті: впли на соціально-трудові відносин в національній економіці

Освіта в системі національної економіки відіграє вагому роль та відповідає за формування кваліфікованих та компетентних людських ресурсів, які виступатимуть на ринку праці в якостіробочої сили. При иьому в умовах стрімкого прискорення соціально-культурних та науково-технічних змін, оновлення знань та набутих компетенцій стає обов'язковою вимогою нашого часу. Таким чином, між сфрерою соціально-трудових відносин та освітньою галуззю існуе беззаперечний зв'язок. Автори зазначили, що на сьогоднішній день в Україні спостерігається розбалансованість між досліджуваними сферами. Так, для ринку праці властиві перенасичення одними спеціалістами (зокрема економічного та юридичного спрямування) та потребою в інших (зокрема робітничих профресій), трудова міграція, незадоволеність роботодавців рівнем знань випускників освітніх закладів тощо. Все це вимагає модернізації існуючої ситуації та узгодження напрямів взаємодії міх сфферою соціально-трудових відносин та освітньою галуззю на державному рівні. Головною метою даної статті є дослідження впливу державного регулювання освіти на розвиток соиіально-трудових відносин в національній економіиі. Практичну реалізацію емпіричного дослідження здійснено за допомогою поєднання методу головних компонент та логіт-моделювання в програмному комплексі STATA 11. Для виявлення інтегрального рівня, що характеризує стан сфрери соціально-трудових відносин в національній економіці України було проаналізовано низку абсолютних та відносних показників, зокрема: рівні безробіття та занятості; продуктивність праці; заборгованість із виплати заробітної плати та ії середній рівень, тощо. Отримані результати свідчать про покращення ситуації у сфрері соціально-трудових відносин в Україні в останні роки. Логіт-моделювання дозволило підтвердити, а також комплексно та індивідуально оцінити вплив макроекономічних, демографічно-міграційних параметрів, а також сукупності характеристик результативності функціонування галузі освіти на рівень гармонізаціі та конвергенції процесів, які відбуваються на праці та освітніх послуг. До того, було визначено пріоритети втручання держави у ссеру регулювання освіти. Отримані результати можуть бути використані для подальших досліджень означеної тематики.

Ключові слова: державне регулювання освіти, соціально-трудові відносини, національна економіка, ринок праці, бінарне логіт-моделювання.

Manuscript received: 07.05.2020

(C) The author(s) 2020. This article is published with open access at Sumy State University. 